\title{
PSYCHOLOGICAL ANALYSIS ON THE ISSUES OF VIOLENCE AGAINST WOMEN IN LANGUAGE AND MEDIA
}

\author{
Ilman Nafi'a \\ Institut Agama Islam Negeri (IAIN) Syekh Nurjati Cirebon, ilmancirebon72@gmail.com \\ Septi Gumiandari \\ Institut Agama Islam Negeri (LAIN) Syekh Nurjati Cirebon, septigumiandari@gmail.com
}

(c) 10 (2)

C2020 by the authors. Submitted for possible open access publication under the terms and conditions of the Creative Commons Attribution-ShareAlike 4.0 International License (CC-BY-SA) license (https://creativecommons.org/licenses/by-sa/4.0/) d DOI : http://dx.doi.org/10.30983/ humanisme.v4i2

\begin{abstract}
Language and media are effective entities to perpetuate male domination over women. Both are representations of various social conflicts, interests, power and hegemony. Through Psychological analysis, this study aims to reveal how both of them can establish the process of 'marginalizing' women. This study used descriptive qualitative methods with secondary data collection techniques through literature review. The results showed that violence against women in language and the media is an invisible form of violence. Language is a person's expression to represent the logic, cultural, social, psychological, philosophical, and political structures of the speakers. It has a goal (teleology) in itself, which is conditioned by the various environmental interests. In patriarchal culture, language is used to build a bad image of women with the aim of strengthening the position of men as the dominant group. The bad image is then used by the media as a general understanding, and implanted into the collective consciousness as the public's subconscious imagination. As a result, whether we realize it or not, women are treated in a subordinate way, but also define themselves in a subordinate way according to men's perspective.
\end{abstract}

Keywords: Language, Media, Violence, and Gender bias

\begin{abstract}
Abstrak
Bahasa dan media adalah entitas yang efektif untuk mengekalkan dominasi laki-laki atas perempuan. Keduanya merupakan representasi dari pagelaran berbagai konflik sosial, kepentingan, kekuasaan serta begemoni. Melalui analisis Psikologi, kajian ini bertujuan untuk mengungkap bagaimana keduanya dapat memapankan proses 'memarjinalkan' kaum perempuan. Kajian ini menggunakan metode kualitatif deskriptif dengan teknike pengambilan data sekunder melalui kajian literatur. Hasil penelitian menunjukan babwa kekerasan terbadap perempuan dalam bahasa dan media adalah bentuk kekerasan yang tidak kasat mata. Bahasa merupakan ekspresi seseorang untuk. mewakili logika, struktur budaya, sosial, psikologi, filosofi, dan politik yang dianut oleh penuturnya. Ia memiliki ketertujuan (teleologi) di dalam dirinya, yang terkondisi oleh pelbagai interes lingkungannya. Dalam budaya patriarkhi, Babasa digunakan untuk membagun image buruk pada perempuan dengan tujuan mengukubkan posisi laki-laki sebagai kelompok dominan. Image buruk tersebut kemudian dicangkok oleh media, dijadikan pemahaman universal, dan ditanamkan ke dalam kesadaran kolektif sebagai imajinasi alam bawah sadar masyarakat. Wal-hasil, disadari atan tidak, perempuan selain diperlakukan secara subordinatif, juga mendefinisikan diri secara subordinatif sesuai dengan perspektif laki-laki.
\end{abstract}

Kata Kunci: Bahasa, Media, Kekerasan dan Bias Gender 


\section{Introduction}

The issues of gender cannot be separated from the problem of injustice and inequality based on gender. ${ }^{1}$ Many events such as discussions, seminars, and even statements of various parties including the government, always explain the importance of justice and gender equality. Unfortunately, whether we realize it or not, in our daily communication and through reporting in various mass media, the ideology that denigrates women will continue to emerge through the choice of words, images and overall vision of the news. ${ }^{2}$ Our verbal and non-verbal media and communication activities will continue to use women as sex commodities and violence.

Language and media are two entities that appear as representations of various conflicts, interests, power, and hegemony. ${ }^{3}$ Both have been accused of being effective tools for strengthening the dominance of men over women through words and images. Through language, polite words are arranged in elegant sentences to keep the process of marginalizing women. ${ }^{4}$ Through the media, the display of

\footnotetext{
${ }^{1}$ Linda Dewi Eriyanti, Pemikiran Johan Galtung tentang Kekerasan dalam Perspektif Feminisme, Jurnal Hubungan Internasional, Vol 6, Issue 1, September 2017, p. 27-37.

2Septi Gumiandari \& Ilman Nafi'a, Women In The Identity Crisis Of Feminism; A Critical Analysis On Gender Movement Based On Islamic Psychology Perspective, Humanisma: Journal of Gender Studies, Vol. 3, Issue 1, January-June 2019, p. 1-12

${ }^{3}$ Muhammad AS Hikam, (1996), "Bahasa dan Politik; Penghampiran "Discursive Practice" in Yudi Latif and Idi Subandy, Bahasa dan Kekuasaan; Politik Wacana di Panggung Orde Baru, Bandung: Mizan, h. 77.

${ }^{4}$ S. H. Ng., Language-based discrimination: Blatant and subtle forms. Journal of Language and Social Psychology, Vol. 26, 2007, p. 106-122.
} continues to be loaded. Violence is likely to continue. ${ }^{5}$ Because, in addition to language and media having authority as the holder of many events, women themselves sometimes justify, underline and take for granted the myth of male domination of women as something given.

This paper will not discuss about the issue of violence against women physically. Because what emerged and the data revealed from the reality of the violence that had occurred so far, in fact, did not reflect the actual facts. While the issue of violence is substantially still rolling and even growing. Like an iceberg that gets bigger and bigger. For this reason, the clash that needs to be anticipated by those who care about gender mainstreaming: activists from non-government organizations or NGO's, is not only visible violence, but violence that uses language and the media. ${ }^{6}$ Therefore, this paper discussed how language and media can become tools for perpetuating gender bias, so that we can always be aware of the socialization of gender bias in both tools.

\section{Method of Research}

This study uses descriptive qualitative methods with secondary data collection techniques through literature review. ${ }^{7}$ Since this

5José Santaemilia and Sergio Maruenda, The linguistic representation of gender violence in (written) media discourse: The term 'woman' in Spanish contemporary newspapers, Journal of Language Aggression and Conflict, Vol. 2, Issue 2, January 2014, p. 249-273.

${ }^{6}$ Yasmin Jiwani, Symbolic and discursive violence in media representations of Aboriginal missing and murdered women, Understanding violence: Contexts and portrayals (2009): 63-74.

${ }^{7}$ Philip M. Davis and William H. Walters, The impact of Free Access to the Scientific Literature: A review of 
study explored about "Psychological Analysis on The Issues of Violence against Women in Language and Media," the first and foremost sources are all literatures including books, journals, writings talking about Psychology of Language, media and gender issues. As much as possible data is attempted to be obtained from primary sources, but it does not rule out the retrieval of data from secondary sources. ${ }^{8}$ To obtain an accurate interpretation about the content of gender bias in Language and Media, the author used Gadamer's Hermeneutic approach. While in analyzing the data, the researcher used content analysis.

\section{Result and Discussion}

1) Women and Violence Issues

"Violence" comes from the Latin word, vis vis which means endurance or strength or latus which means carrying so that it can be interpreted literally as power or strength to bring. ${ }^{10}$ In Nursyahbani's opinion, violence is an attack and physical and psychological abuse on a person, destruction or something that can potentially repress other people's personalities. ${ }^{11}$ From this understanding, it can be understood that the word "violence" can be interpreted as an activity that forces and harms

Recent Research, Journal of the Medical Library Association: JMLA, Vol. 99, Issue 3, July 2011, h. 208.

8Sugiyono, (2010), Metode penelitian kuantitatif, kualitatif \& $\mathrm{R} n D$, Bandung: Alfabeta.

${ }^{9}$ Klaus Krippendorff, (1981), Content Analysis; Introduction to Its Theory and Methodology, Translated by Farid Wajidi. Jakarta: Rajawali Press, h. 15.

${ }^{10}$ Reza Riana Putri, (2012), Kekerasan dalam berpacaran. Dissertation of Universitas Muhammadiyah Surakarta University.

${ }^{11}$ Nursyahbani, (2001), Aspek bukum kekerasan terhadap perempuan, Madura: STAIN Pamekasan Press.

Septi Gumiandari dan Ilman Nafi'a others, both in the physical and psychological sense. $^{12}$

In general dictionary of Indonesian, arranged by WJS. Poerwadarmita, violence is defined as (1) Manly, strong, mighty (2) forced, rape; (3) subjecting. ${ }^{13}$ Meaning of violence above is very interesting to study, because violence (acts of crime) in our Indonesian language is equated with the word gallant, strong and mighty (a trait that is often proud of, which every parent expects for his son)?

Susan Brownmiller in her book "against our will", provided a terminological definition of violence as a means of social control that aims to regulate the space for women. ${ }^{14}$ Because the reality of the social context that gave birth to violence as well as the social constructs associated with that context revealed a dynamic pattern of the occurrence of violence, where various studies indeed prove that women are often used as preys or objects that should be carried out sexually by men. Violence that has taken place so far is often oriented to crimes that target victims based on gender. $^{15}$ So the measure of violence, consciously or unconsciously, is aimed at maintaining the supremacy of the physically strong, namely the men.

This phenomenon is rooted in social patterns which, according to Black, prefer to see violence as a means of venting grievances

\footnotetext{
${ }^{12}$ Michela Menegatti and Monica Rubini, Gender bias and sexism in language, Oxford Research Encyclopedia of Communication. September 2017, p.1-24.

13Poerwadarmita, (1980), Kamus Umum Bahasa Indonesia, Bandung: Penerbit Hasta, h. 79.

${ }^{14}$ Susan Brownmiller, (1975), Against Our Will, New York: Oxford University Press, h. 34.

${ }^{15}$ Teri Sobari, Kekerasan Simbolik dalam Bahasa Lirik Lagu, Penelitian-Pendidikan, Vol. 10, Issue 1, May 2011, p. 144.
} 
through aggression. ${ }^{16}$ From the perpetrator's perspective, the victim is deviant deviating from the norms favored, and as such, acts of violence are a form of social control in which the purpose of the action is to carry out conflict management, carry out punishment, or take revenge. So that when it is seen using a feminist perspective, what happens is how to put women with violence control devices to fit the desired flow.

Violence against women is an extension and a logical consequence of various stereotypes about and against it. Woman is a vulnerable and potential community to be a victim of misrepresentation about herself. Namely violence caused by gender bias, which in feminism literature is commonly called gender-related violence.

Domestic violence against women is often highlighted in this context. Feminists always seek solutions for women to get out of this form of violence. Whereas outside of this domestic crime, there are other forms of violence that are actually more potential and complex, making it difficult to anticipate in one analytical model, namely women's violence in the media and language.

2) Violence Against Women in Language

Language, mind and culture are inseparable entities. Language is not only formed, but also forms humans. We understand the world in the mind that is influenced by the vocabulary that we have. We speak or perceive reality based on the available

${ }^{16}$ James Black, (1983), The War against women, London: Penguin, h. 12.

Septi Gumiandari dan Ilman Nafi'a vocabulary reserves that are shaped in our long socio-cultural history. ${ }^{17}$

Humans live within language. Language at the same time can be a window to the world and prison of the mind. Through language, humans express hatred and love, sorrow and joy, longing, revenge, and emotion with others. With language, human beings fall into reality. Language seems to be the mouth of representation where the meaning of life is lived, absorbed, then removed from our consciousness. $^{18}$

For this reason, it is also normal for postmodernists and post-structuralisms to see language not only as a means of communication, but also as a place for the upheaval of various interests and powers. ${ }^{19}$ This historical process of language can start from the fabrication or political culture of society. Consciously or not, for example, we often use words that are difficult for common sense to accept. That's when language becomes a prison of reason. Language becomes a place for the conquest of imagination space so as we fence off our minds in interpreting reality from a powerful lens.

The enormity of a word. Women have been affixed with the signification of 'satisfying This is considered as an important part of the operation of the 'language regime' to strengthen

${ }^{17}$ Ahmad Mubaligh, Relasi bahasa dan ideology, Lingua: Jurnal Ilmu Bahasa dan Sastra, Vol. 5, Issue 2, Desembser 2010, h. 112-118.

${ }^{18}$ Lis Lisnawati, Psikolinguistik dalam Pembelajaran Bahasa, Educare, Vol. 6, No. 1, Agustus 2008, h. 31-43.

${ }^{19}$ Foucault, (1972), The Archeology of Knowledge and The Discourse on Language, New York: Pantheon Books, h. 24. 
the hegemony of the centralized regime. ${ }^{20}$ In other words, language must be understood as something that has a purpose (teleology) in itself, which is conditioned by various environmental interests. Therefore, choosing a word in the language means choosing a particular purpose to be achieved. ${ }^{21}$ Borrowing the term used by Gadamer, that accidental words or expressions never have a standard. Language has its own goal (telos) or is full of intentions. Therefore, every word is never meaningless. ${ }^{22}$

Furthermore, according to Jacques Derida, a postmodernist figure, language is intentionality. Language is not a row of readymade words which are then freely chosen by the user. Even though humans master language, they are not free to say certain words as they wish. They must think about how it will impact people and others on their words and their choice of words. ${ }^{23}$ This fact at least helps us explain why language is also said to have participated in the construction of women in their position as the second class citizen.

Ferdinand De Saussure further developed the elements of meaning and words in language through theories about the concept and the sound image. For example, the word

${ }^{20}$ Jonathan Pool, (1990), Language regimes and political regimes, In Language policy and political development, Ablex Publishing, h. 241-261.

${ }^{21}$ Floretta Boonzaier, The Life and death of Anene Booysen: Colonial discourse, gender-based violence and media representations, South African Journal of Psychology, Vol. 47, Issue 4, 2017, p. 470-481.

${ }^{22}$ Hans George Gadamer, (1977), Philosophical Hermeneutics, London: University of Californis press, h. 27.

${ }^{23}$ Barbara Johnson, The Frame of Reference: Poe, Lacan, Derrida, Yale French Studies, Vol. 55, Issue. 56, July 1977, h. 457-505.

Septi Gumiandari dan Ilman Nafi'a tree consists of the imagination of the word "tree" (signifier) and the concept of tree (signified). ${ }^{24}$ The symbolic system of language is based on the system of human life. Because of that the vocabulary of a language in addition reflects the ability of a community to express their life experiences. ${ }^{25}$ Besides that, they generally reflect their knowledge, outlook on life, beliefs and thoughts. English reflects the overall political, social and cultural history of the British people Likewise with Javanese. The division of words into three levels shows that there is a patriarchal culture which is very thick in the speakers' community. ${ }^{26}$ The division of words in low (ngoko), middle (madyo) and upper (inggi) refers to the existence of social strata of society in Javanese culture.

The patriarchal culture manifested in our society in general seems to reinforce the myth that women are physically weak, fragile, indecisive beings. ${ }^{27}$ Therefore women must be protected, loved and praised. By nature women are also seen as less intelligent, so that they are only worthy of doing work that is domestic and has little to do with the public world. The public area is the responsibility of men, because it is feared that women will not be able to solve it. While men are described as being knights, always strong, brave, and so on. ${ }^{28}$ Even with regard to ideology, God is revealed in male

${ }^{24}$ Johnson, The Frame of Reference...Ibid.

${ }^{25}$ Nur Hasnah, Bias Gender Dalam Buku Ajar AlArabiyah Linnaasyiin, Humanisma: Journal of Gender Studies, Vol. 1, Issue 1, January- June 2017, p. 61-74

${ }^{26} \mathrm{Ji}$ Ho Park, Jamin Shin, and Pascale Fung, Reducing gender bias in abusive language detection, arXiv preprint arXiv:1808.07231 August 2018, p. 1-6.

${ }^{27}$ Jinni A. Harrigan and Karen S. Lucic, Attitudes about gender bias in language: A reevaluation, Sex Roles 19. Vol. 3, Issue 4, 1988, p. 129-140.

${ }^{28}$ Harrigan, at al., Attitudes about...Ibid.

Psychological Analysis on The .... 
figures. Even Catholics in prayer declare the father, son and Holy Spirit. Where in English, God's pronoun is He (male Pronoun). ${ }^{29}$

A brief stereotype against women as revealed above puts women in a safe position because they are protected. But actually the overall attributes attached to women actually weaken the existence of women as humans. Yet according to Kant and Hegel, humans; men and women, are producers of very productive big ideas. The long history of the world is filled with great human ideas, including women. ${ }^{30}$

Christ Weedon, a post structuralist, said that language is also an area where a sense of self, subjectivity, including definitions of women and men as well as the good and bad of each of these types are formed. This happens because language is a social activity that is structured and bound to certain social conditions. ${ }^{31}$ According to Terry Eagleton, language is also a site for ideological impacts that have tremendous power to shape the behavior of its readers. ${ }^{32}$ Thus, the discussion about ideology cannot be separated from the discussion about language.

Therefore, when wanita tuna susila (a prostitute) is said to be a prostitute, whereas, prostitution is an activity that involves at least two parties; who prostitute themselves and

${ }^{29}$ Muhammad Jafar Shodiq, Bias Gender dalam Buku Bahasa Arab Siswa MA Kelas X dengan Pendekatan Saintifik 2013, Jurnal Pendidikan Islam, Vol. 3, Issue 2, December 2014, p. 307-326.

${ }^{30}$ Frans Magnis Suseno, (2000), Pengantar melawan kekerasan tampa kekerasan, Yogyakarta: Pustaka pelajar, p. 56.

${ }^{31}$ Chris Weedon (ed.), (1997), Post-War Woman's Writing in German: Feminist Critical Approaches, Berghahn Books, p. 965. 123.

${ }^{32}$ Terry Eagleton, (2014), Ideology, Routledge, p.

Septi Gumiandari dan Ilman Nafi'a people who use these services. There's even a pimp, who is the luckiest. But who exactly is immoral? Not the pimp, not the one who uses prostitution, but the woman. And why is it also not the party of men who are called prostitutes, so there is the term pria tuna susila. From this explanation it can be understood, that behind the choice of these words there is a meaning that clearly insults women's dignity. This is the lust of men' and still being abused as a prostitute. The same thing happened with the word policewoman. Why is the word police always associated with men? Whereas if there is a female police officer, she is called a policewoman. But words like secretaries, nurses, helpers are professions related to domestic affairs, directly refer to women. These words were chosen not without purpose, but have an orientation to in turn position women as subordinated beings. ${ }^{33}$

What is very ironic is gender discourse itself. Not a few of our society, including universities, who often assume the word gender with a discourse about sex. This reality can be felt directly by us. Whenever there is a study of gender, what occurs in the brain cells of men and not a few women are issues that are considered sexy, so that not a bit of pornography that ignorant coloring the study of gender. This is a proof of how marginalized women are in language. ${ }^{34}$

The above conditions are further exacerbated by the misinterpretation of

${ }^{33}$ Mudjia Rahardjo, Kekerasan Terbadap Perempuan Dalam Bahasa dan Media, El-Harakah; Jurnal Budaya dan Islam, Vo. 3, Issue 1, Jan-March 2018, p. 1-8.

${ }^{34}$ S. Sczesny, Formanowicz, M., \& Moser, M., Can gender-fair language reduce gender stereotyping and discrimination?, Frontiers in Psychology, Vol. 7, Issue, 25, 2016, 3-8. 
religious texts, where Arabic is often the root of gender bias in the religious discourse. No doubt, that language is a manifestation of the culture of the people. ${ }^{35}$ For this reason, when the culture that surrounds a society is gender biased (patriarchal) culture, the language that manifests will imply that culture. Likewise with the Arabic language that was born from the patriarchal culture of the Arabs. Therefore, Arabic grammar also contains gender bias because it reflects the culture and attitudes of Arab society towards women. ${ }^{36}$ History proves that at the time of the coming down of the Koran, the presence of a daughter could be seen as threatening the honor of an Arab family so that the burial of a baby girl alive was taken to cover up the disgrace. ${ }^{37}$ This burial was taken because the public did not yet know about abortion. The value of women is nothing more than goods that can be sold and inherited. ${ }^{38}$ In addition, the low position of women in Arabic culture can be seen in reality, where men can marry an unlimited number of women at the same time, divorce them, refer again whenever and how many times men

${ }^{35}$ Nofri N. Andi, Analisis Terhadap Hadis-Hadis Pemberdayaan Perempuan, Humanisma: Journal of Gender Studies, Vol. 2, issue 2, Juli- Desember 2018, p. 159-166.

${ }^{36}$ Ismail Suardi Wekke, Gender dalam Materi Belajar Bahasa Arab di Pesantren, Turast: Jurnal Penelitian dan Pengabdian, Vol. 1, Issue 1, 2013, p. 55-56.

${ }^{37}$ This reality is recorded in the verses of the Koran as follows: "When it was reported to someone among them about the birth of a daughter, she was sullen in holding sadness. She hids from the crowd because of the bad news she received, maybe she would maintain it with contempt. or bury them (alive) in the ground, how bad their decisions are." (al-Nahl: 58-59).

${ }^{38}$ At-Thabari, (2000), Jami' al-Bayan, Kairo: Maktabah al-Syamelah, p. 599.

Septi Gumiandari dan Ilman Nafi'a want. ${ }^{39}$ Quite often women are seen as devils who must be shunned. ${ }^{40}$

When Arabic is accommodated in the language of the Koran, it is inevitable, the language of the Muslim community also in turn contains a gender bias that affects the textualization process of the word of God in the form of the Qur'an. ${ }^{41}$ This mindset is possible for some people who view language as gender neutral will be amazed and even criticize the genealogy of this thought.

The above thought does not imply that the writer doubts the validity and authenticity of the Qur'an. The author believes that the truth and validity conveyed by the Koran are universal and eternal, but the process of verbalization is closely related to the condition of Arab society in the descending period. ${ }^{42}$ Related to this, Ibn Khaldun with a bolder tone said, that the Qur'an was revealed in Arabic and adapted to their rhetorical style so that it can be understood. ${ }^{43}$ Records of the dialogue between the verses of the Qur'an and the Arab community, especially those closely related to their personal problems, are a strong indication of the relevance of the discussion of the

${ }^{39}$ At-Thabari, Jami' al-Bayan...Ibid., p. 534-535

${ }^{40}$ Women are demons created for men, we take refuge in Allah from the worst of tempting demons. See Muhammad bin Iyas. (1982). Bada'i al-Zubur fi Waqai alDubur. Beirut: Maktabah Saqafiyyah, p. 52.

${ }^{41}$ Junaidi Abdillah, Radikalisme Agama: Dekonstruksi Tafsir Ayat-Ayat "Kekerasan" Dalam AlQur'an, Kalam: Jurnal Studi Agama dan Pemikiran Islam, Vol. 8, Isuue 2, December 2014, p. 281-300.

${ }^{42}$ Dede Rodin, Islam dan Radikalisme: Telaah atas Ayat-ayat Kekerasan dalam al-Qur'an, Addin, Vol 10, Issue 1, February 2016, p. 29-60.

${ }^{43}$ Ibnu Haldun, (2011), Muqaddimah, Beirut: Darul Fikir, p. 438. 
absolute truth of the Qur'an to the local conditions of the Arabs during the descent.

For this reason, when the majority of Muslims have the awareness about the text of the Koran which is as azali and eternal as Allah, then a tendency is born to understand it textually. This belief raises serious problems because the texts of the Koran are records of social change that took place during the 23 years of Muhammad's apostolate. Therefore, the textual approach would suggest contradictory verses between one and others. This problem is overcome by the ulama through the concept of naskh, which is to erase or delay (to an indefinite period of time) a number of verses by prioritizing other verses to be enforced. This concept implies that the text of the Qur'an cannot be applied simultaneously and comprehensively: something that is contrary to the doctrine of eternity of the text of the Qur'an. ${ }^{44}$

Among the examples of gender biases in Arabic grammar that can be explored in this paper are the use of the name (isim) in Arabic which is always gender (mudzakkar or mu'annats), it can be intrinsically or majazi. Just as one cannot ignore social class when speaking Javanese, the above rules make a person unable to avoid classifying men and women in Arabic because there is no neutral name in this language.

As Arabic users, the text of the Koran follows this provision so that Allah as the Essence of a non-gender also has a gender name, mudzakkar (male) so that it uses the male verb (fi'il mudzakkar), as indicated by the following verse:

${ }^{44}$ Triana Sofiani, Tafsir Agama Dan Kekerasan Berbasis Gender, Jurnal Penelitian, Vol. 5, Issue 2, November 2013, p. 1-14.

Septi Gumiandari dan Ilman Nafi'a
"Verily, your Lord is Allah Who created the heavens and the earth in six periods, then $\mathrm{He}$ dwells on Arsy to arrange all matters. No one will give shafa'at except after His permission. (Essence) that is Allah, Lord you, then worship Him. Then do you not take lessons?" (Qur'an, Yunus: 3)

Another provision in Arabic grammar that contains gender bias is that isim muannats (names for women) is sufficient to be formed by adding only one letter ( $t a^{\prime}$ marbuthoh) to the name or isim that already exists for men, like the word ustadzah (female teacher) which is formed from the word ustadz (male teacher), Muslim women, etc. This grammar reflects the perspective of Arab society on the existence of women as a (smaller) part of the existence of men.

The influence of perspective that ignores the existence of this woman in the Qur'an can be seen in the verse about wudlu as follows:

"O you who believe, if you want to pray, wash your face and your hands up to your elbows, and sweep your head and (wash) your feet up to your ankles, and if you junub then take a bath, and if you are sick or deep travel or return from the toilet or touch a woman, then you do not get water, then count with good soil (clean), sweep your face and your hands with the land. God does not want to trouble you, but He wants to clean you and perfecting His ni'mat for you, so that you will be grateful. (Surah al-Ma'idah: 6)

The verse is very clearly speaking only to men because it clearly mentions touching women (with all their connotations) as a cause 
of cancellation of male "holiness". ${ }^{45}$ There is not one fiqh scholar who draws conclusions from the above verse that women touching women can cancel wudlu. Thus, the existence of women in the above paragraph does not exist and the provisions for women are quite derived from the provisions of men.

Another Arabic grammar that contains gender bias is the plural noun (jama) for a group of women is a plural male word (jama mudarkear) even though only one male is found in it. One group of women, either one thousand, one million, a billion, even more, will use the pronoun jama' mudzakkar (male) only because there is one man in the sea of women. This reflects the perspective of Arab society that a male presence is more important than the presence of many women, whatever the number. ${ }^{46}$

As Arabic users, the Qur'an also follows this provision so that in conveying a message addressed to the general public, whether male or female, the Qur'an uses male words. Some examples of verses can be mentioned here: "O you who believe, are required for your fasting as required by those before you so that you will fear Allah." (al-Baqarah: 83).

"And do the prayers and pay zakat. And all the good you do for yourself, you will get it (reward) with Allah. Indeed, Allah is All-Seeing what you are doing." (alBaqarah: 110).

${ }^{45}$ Ahmad Atabik, Wajab Maskulin Tafsir al-Qur'an: studi intertekstualitas ayat-ayat kesetaraan Gender, Palastren: Jurnal Studi Gender, Vol. 6, Issue 2, December 2016, p. 299-322.

${ }^{46}$ Nasr Hamid Abu Zaid, (2011), Women in the Discourse of Crisis, Cairo, Egypt: The Legal Research and Resource center for Human Right pages. (LRRC).

Septi Gumiandari dan Ilman Nafi'a
Masculinity of the verses above lies in the use of words in italics. The pronoun for kum people (you), the conjunction of alladhina (people who), the verb aamanuu, tattaquun, aqümuи, aatuu, tuqoddimuи, tajidun (faith, piety, establish, work on, work on, work on). These words in their female form (muannats) are kunna, allaatii, aamanna, tattaqna, aqimna, aatina, tuqoddimna, tajidna. Although using the word mudzakekar, this verse is clearly aimed at all Muslims, including women. If not, then the verses above cannot be used as a basis for the obligations of prayer and rakat for women.

Although women have been represented by mentioning men, but on several occasions, the verses of the Qur'an use a style of language in which the existence of women is not melted by the presence of men. For example the following verse: "Verily Muslim men and women, male and female believers, men and women who remain in obedience, men and women who are true, men and women who are patient, solemn men and women, alms men and women, fasting men and women, men and women who maintain their honor, men and women who chant many (names) of Allah, Allah has provided for them mercy and great reward." (al-Ahzab: 35).

Arabic is not the only language that recognizes gender differences. English also has pronouns she for women and he for men. As in Arabic, male domination of women in British society is reflected in general terms that use the word male, for example chairman and spokesman. When awareness of equal rights between men and women arises among the English-speaking community, then there is also a different awareness in language. For example the use of the word he or she to avoid using he excessively, and changing masculine terms such 
as chairman and spokesman into more neutral words such as chairperson and spokesperson. This kind of awareness is not found in Arabic discourse. $^{47}$

Gender bias in the language of the Koran will then contain great potential for the emergence of biased religious interpretations. The verse about inheritance for example, at the time of its downturn contained the spirit of economic empowerment of women. Those who had been inherited, then changed to be able to inherit or obtain an inheritance and finally be able to also inherit or give inheritance. From this transformation it can be captured that the half of girls contains a message that half is the minimum amount acceptable to women. In the same verse it is even stated that the portion of the woman (mother) is the same as the man (father), as he said: ".... And for both mother and father, each share one-sixth of the property left, if he (who died) had children." (al-Nisa: 11).

The textual approach to the verses of the Koran must be watched because it has a tendency to ignore the spirit of empowerment in all verses related to gender. Muhammad Abduh indicated that most of the words of the Koran had changed their meaning even in the near future after their descent. ${ }^{48}$ This change in meaning can occur in the form of an understanding of the Qur'an which is contrary to its original spirit.

If the al-Qur'an which is believed to have no problem in its authenticity already contains the potential for the birth of gender-biased religious discourse, then it can be estimated how much the potential for other religious

\footnotetext{
${ }^{47} \mathrm{Abu}$ Zaid, Women in the Discourse of Crysis...Ibid.

${ }^{48}$ Muhammad Abduh, (1367), Al-Manar, Kairo: Darul Manar, jilid. I, p. 21.
}

Septi Gumiandari dan Ilman Nafi'a texts such as Hadith, Tafsir, Figh, etc. in giving birth to biased religious discourse. In contrast to the text of the Qur'an, the hadith can be problematic in terms of narration and redaction (sanad and matan). Therefore voluminous hadith is multilevel; saheeh, hasan, dloif and maudlu'. The highest level of hadith is the hadith which is sanad or matan contains no defects.

Hadiths that contain gender bias are very easy to find. Some examples can be mentioned here: "Among men's rights is if the husband's blood and pus flowed between his nose and his wife was licking with his tongue, women had not fulfilled her husband's rights. If only humans could prostrate to humans, I would have ordered a woman to prostrate to her husband. "(HR. Al-Hakim). ${ }^{49}$

This hadith is quoted by Imam Nawawi in the book of Uqud ad-Dulujain. Until now, the book is still considered as the main reference in several Islamic boarding school in Indonesia. The results of the Yellow Book Study Forum (FK3) showed that the quality of the hadith was weak (dha'if), because there were problematic narrators, namely Sulayman bin Dawud and alQasim. Imam Nawawi also quoted the three badiths below: "If a wife spends the night leaving her husband's bed, then the angels curse her until morning." (Narrated by Bukhari Muslim).

"If a woman spends her nights praying, during the day for fasting, then her husband calls her to bed while the wife delays him for a moment, then later on the Day of Judgment she will be dragged with chains and fetters, gathering with demons until she arrives in the lowest possible place."

${ }^{49}$ Forum Kajian Kitab Kuning, (2001), Wajah Baru Relasi Suami-Istri, Yogyakarta: LKiS, p. 94. 
"That the woman cannot fulfill the rights of God before fulfilling the rights of her husband. Suppose the husband asks his wife while the wife is on the back of a camel, then she must not reject him." (Narrated by al-Thabarani). ${ }^{50}$

The above hadiths, if understood textually, would imply that men (husbands) as female leaders (wives), even ironically can also be used as a justification for the ability to control, oppress even become a validity to carry out repressive actions (violence) for men over women. In fact, if it is understood contextually, the word "la'nat" (curse) and various repressive actions above in the terminology of the hadiths are applied to women who refuse without a reason that can be justified by the syar'i when invited to 'sleep' by her husband, while he is loose.

And the term "la'nat" in this hadith does not have to be interpreted as the punishment of the afterlife which will cause women to go to hell, but it must be better understood as an atmosphere of disharmony between husband and wife. Besides of course, this term does not only apply to women, but also vice versa, to men. And there are many more interpretations of classical scholars who are gender biased, which sometimes have brought forth the status quo of male domination and supremacy over women.

\footnotetext{
${ }^{50}$ Based on the research of Husein Muhammad, this book which makes a wife's obedience to her husband as a central theme contains about 100 hadiths. 20 of these traditions have the status of la ashla labu (unclear). In addition, Khalid bin Muhammad azZuwaidi also found 31 hadith maudlu (fake) in the same book. Husein Muhammad, (2001), Fiqh Perempuan; Refleksi Kiai atas Wacana Agama dan Gender, Yogya: LKiS Pelangi Aksara, p. 180-183.
}

When examined from the series of rijal alHadith, the hadith above and other hadiths are generally problematic in sanad and entirely problematic in terms of matan. Khalid M. Abu el Fadl mentions three things as the reason for the invalid traditions according to matan, which is contrary to the absolute sovereignty of God and God's Will, not in harmony with the Qur'anic discourse on married life, and not in line with the entire narration describing the Prophet's behavior towards his wives. ${ }^{51}$

Some other supporting factors in the birth of a biased religious discourse is the fact that the formulation of religious teachings from the beginning was dominated by the Arabs, a nation that has a pre-assumed bias in viewing women. Until now the discourse of Religion is still oriented to Arab countries, so that not only are unequal relations between men and women that they instill in the awareness of Muslim communities throughout the world, but also unequal relations between Muslims and nonMuslims based on the bitter experiences they experience until now in Arab lands.

3) Violence against Women in Media

Like the words of the prophet, the media so influences perceptions, thoughts of the masses, and even human behavior. In the era of communication, the media is a new religion for the industrial community. ${ }^{52}$ Electronic and printed information sources become the primary consumption of people's lives, thus directing people to continue to depend on the

${ }^{51}$ Khaled M. Abou el Fadl, (2004), Atas Nama Tuban: dari Fikib Otoriter ke Fikih Otoritatif, transated by R. Cecep Lukman Hakim, Jakarta: Serambi, p. 311.

${ }^{52}$ Patricia Easteal, Kate Holland, and Keziah Judd, Enduring themes and silences in media portrayals of violence against women, Women's Studies International Forum, Vol. 48, Jan-Feb 2014, p. 103-113. 
existence and presentation they provide, including its influence. In other words, the media is an entity that has enormous power that can mobilize and shape public opinion.

A series of history proves how the media has tremendous power to build public perception about the presidential candidates they like. Public opinion towards a presidential candidate can change drastically once the media includes its weaknesses, but at the same time, a candidate can be lifted in popularity as soon as the media includes his strengths. Therefore, new assumptions emerge, that "whoever wants to seize and maintain his power, he/she must control the mass media." ${ }^{53}$

Likewise in a form of social control in which the purpose of action is to conduct conflict management, the media are used to establish social security. So that when viewed through a feminist perspective, what happens is how to condition women with violent control tools to fit the desired path through the media. In patriarchal culture of Indonesia, women are created with a variety of portrayals that illustrate the weaknesses, as well as the sensationalist of women's bodies which shows their powerlessness over the supremacy of men.

Once in a while, let's try to observe various media, print or electronic, it will easily be posted various news titles that weaken and have negative connotations towards women as if coloring social conflict in this country. The rape event that was accompanied by murder will surely become a big headline in the mass media. Why the incident happened, how the background of the perpetrators, and how the suffering of the victims thereafter is rarely or

\footnotetext{
${ }^{53}$ Mas'ud Said, (2000), Clinton, Wanita dan terpaan Media, Jawa Pos, Kamis, 23 Juli 2000.
}

Septi Gumiandari dan Ilman Nafi'a even not published. This is the evidence according to Watts (1999) referred to as media bias. ${ }^{54}$ The media will only show events that they like and no longer put forward the aspect of objectivity, but more on commodities and public consumption.

The rise of women who flew in the television world in the country through various advertising products that have clearly reduced their bodies to commodities, must be seen as efforts by various parties to exploit and control women through the media industry. A number of empirical calculations of the creation of women's styles that exhibit body parts and erotic movements are a source of income for those engaged in the sex industry and as a 'pleasure' for the users of their services and as a justification for the form of helplessness of women over men. Through the media, men limit the power of women, so that women are always considered to be number two after men. The position of women is installed as a complement to men.

Likewise with a variety of media in the public discourse space, especially the tabloids and magazines that point to the element of pornography, now it is increasingly troubling. But isn't pornography in the media that is rife produced because of the high public interest in consuming it? so it is not wrong if Indonesia is then attached with the title as a country of "pornographic paradise" after Russia. Pornography in Indonesia is considered far more serious than Thailand, which has been known to be open and vulgar in terms of pornography.

${ }^{54}$ Mark D. Watts, Elite cues and Media bias in Presidential Campaigns; explaining public perceptions of a liberal press, New York: Communication Research Journal, Sage Publication, Inc. Vol. 26, issue 2, April 1999, p. 144-175.

Psychological Analysis on The .... 
Pornography is a form of sexual violence that places women in graded physical and mental conditions. ${ }^{55}$ The legitimacy of pornography in Indonesia is often connected with the issue of press freedom, which of course cannot be separated from the issue of censorship and the rule of law that gave birth to pornography. The fear of the existence of censorship and the rule of law that also gave birth to another debate, namely around the problem of boundaries between art and pornography. Even now there are no clear boundaries regarding what is referred to as pornography or the results of artistic creations.

The Minneapolis ordinance has justified the notion that sexual stimulation has contributed to violence against women. He further stated, Pornography is the theory - rape is the practice of male domination, or it could be said that pornography is violence against women. ${ }^{56}$

In eastern societies, sex is very taboo and women are reluctant to express their sexual or erotic feelings through pictures or writing in public. But often due to socio-economic factors, women are forced to just approve what has been taboo by the community and are set up in such a way as to follow the directions of the producer, even though they fully understand that pornography is a form of insult to the dignity of their own people.

${ }^{55}$ Gert Martin Hald, Neil M. Malamuth, and Carlin Yuen, Pornography and attitudes supporting violence against women: Revisiting the relationship in non-experimental studies, Aggressive Behavior: Official Journal of the International Society for Research on Aggression, Vol. 36, Issue 1, 2010, p. 14-20.

${ }^{56}$ Gillian Rodgerson and Elizabeth Wilson, (1993), Pornography and Feminism; the case against consorship, in Stevi Jackson, New York University Press, p. 288.
Even though Indonesian law rules have emphasized the prohibition on broadcasting pictures or writing or materials that violate immorality or politeness (KUHP article 282) and the prohibition on broadcasting images, writing or materials that arouse sexual arousal (KUHP article 533). But again, because of the ambiguity of the line between art and pornography, it has caused its own difficulties in law enforcement. For this reason, in the future it is necessary to formulate more clearly what is meant by pornography especially to protect women from exploitation of their bodies and the possibility of developing pornography as a cause of violence against women.

Departing from the aforementioned problems, conducted research on the phenomenon of girls who were used as photographs of pornographic tabloid models. The rise of pornographic media turned out to have spawned a link and a model search network to be used as a show off body. ${ }^{57}$ Of concern, it turns out that some of the models recruited were girls aged 15-18 years on the grounds that children's bodies were considered natural bodies. And, on the other hand, they are easily fooled and persuaded and do not ask for a professional salary.

This research wants to reveal why girls are the target of sex exploitation in the pornography industry. From the results of Listya Adi Gardhiani's research, a significant relationship exists between consumerism culture that dominates modern society today

\footnotetext{
${ }^{57}$ Supadiyanto, Pornography In Print Media: Legal Review Of Pornografic Content On Mantra Tabloid In Indonesia, Journal Of Social Studies, Vol. 15, Issue 1, 2019, p. 4662.
} 
and pornography discourse. ${ }^{58}$ There is no doubt that being a famous artist or model is the imagination of most young women. Some of them often use instant and easy ways to reach their goals. Until they are not aware, they are trapped in pornographic activities that harass them.

The pattern of life in big cities, like Jakarta, modern and everything is measured by the value of money. As a place of very high money circulation, Jakarta is able to make teenage girls strive to achieve their dreams. Such a modern and glamorous life is able to invite teenagers to become part of it. Along with the development of mass media, especially electronics, which presents that the world of entertainment feels beautiful and fun, able to lull the dreams of young girls to become soap operas, singers, or photo models.

The selection of talented girls in the field of cinema or sound, or casting models to become stars or advertisements, will certainly be welcomed with enthusiasm. In the end, the thing to be achieved is success, namely popularity and material needs. By becoming films and soap operas, magazine models or photo models of the catwalk, young women are racing to be able to reach their dreams of becoming famous models so that they gain popularity and money. In fact, the road to get there is not easy.

Achieving success as an artist or model is not easy, there are heavy stages that must be passed. However, behind that it turns out there is an "easy" way to be able to make money. For example, in some cases, prospective models take shortcuts that plunge them. Finally, they

\footnotetext{
${ }^{58}$ Jude Elund, Masculinity, mass consumerism and subversive sex: A case study of Second Life's 'Zeus' gay club. Sexualities, Vol. 16, Issue 3-4, 2013, p. 423-444.
}

also appear as magazine models that are fun. However, because they wanted to be famous soon, the young women tried to be peaceful in this way. They dare to appear posing in the tabloids whose readers are adult men, or even pornographic magazines. The opportunity was quite open. Bearing in mind, more and more media in that segment have helped decorate the choice of media for the community.

A female model has unwittingly been positioned in a beauty myth made by men. The image of a beautiful and attractive woman is a tall slim body, long and straight hair, smooth white face, and beautiful eyeballs through blue or green contact lenses. It was all constructed for the benefit of men. ${ }^{59}$ As a result, there was an exploitation of the female body in the form of sexual exploitation as a commodity in the form of pornography that was actualized through the media.

$$
\text { Pornography is an expression of }
$$
hegemonic masculinity in people's lives. Pornography is made primarily for male consumption that women are the main object of property. ${ }^{60}$ In this case, women are considered to have high selling points with the appearance and sexiness of the body that is displayed. Here women's bodies are exploited through photographs with semi-nude poses, or even naked from children's bodies, and photographed. Various matters related to women's sexuality are then packaged in

${ }^{59}$ Diana Damean, Media and gender: Constructing feminine identities in a postmodern culture, Journal for the Study of Religions and Ideologies, Vol. 5, Issue 14, 2010, p. 89-94.

${ }^{60}$ Thomas Johansson and Nils Hammarén, Hegemonic masculinity and pornography: Young people's attitudes toward and relations to pornography, The Journal of Men's Studies, Vol. 15, Issue 1, 2007, p. 57-70.

Psychological Analysis on The .... 
provocative language to simply increase the tension of the readers' public libidity.

The phenomenon of pornography has expressed the high level of exploitation of women. Women become sex objects, even violence. Women's sexuality is then only mastered, perceived, and then produced with male perspective values. Producers who produce pornographic material, whether they are women or men, are in a patriarchal culture. Sexuality is controlled by men, with men's tastes. ${ }^{61}$ Unknowingly, or consciously, the girls who become adult media models become the object of commercialization.

In pornographic tabloids, what is offered to readers is the sensuality of the female body. ${ }^{62}$ Other matters beyond the sexual problems and sensuality of women are only as a complement. Selling the sensuality of a woman's body certainly needs a model to be sold. The women involved in the photo shoot must meet certain physical criteria. Breasts contain, straight hair, white, slim, and proportional-according to the version of male readers. The more criteria a female model can meet, the more expensive her body's selling price will be.

Likewise in the political arena, violence against women via mass media is seen. ${ }^{63}$ If male politicians win the race for elections, the media will take pictures and expose the politicians side by side with their respective wives. Then it was

${ }^{61}$ Nancy F. Cott, Passionlessness: An interpretation of Victorian sexual ideology, 1790-1850. Signs: Journal of Women in Culture and Society, Vol. 4, Issue 2, 1978, p. 219-236.

62Supadiyanto, Pornography in Print Media...Ibid.

${ }^{63}$ Alessia Tranchese and Sole Alba Zollo, The Construction of Gender-based Violence in the British Printed and Broadcast Media, Critical Approaches to Discourse Analysis Across Disciplines, Vol 7, Issue 1, 2013, p.141 163

Septi Gumiandari dan Ilman Nafi'a reported, the success of the politician was inseparable from the role of his wife. The wives are only as a support and complement for the husband, they are not themselves. But if women politicians are successful in the political arena, they will stand alone without their husbands. The media is ignoring it, as if it's not something worth covering. Look at the case of the rise of Zuzana Caputova as president of Slovkia. The public did not know much about Caputova's husband. Who doesn't know Michelle Obama, as the wife of former United States President Barack Obama? Who does not know Mrs. Iriana Joko Widodo, as the recently Indonesia president's wife? Why this happened? Because of the strong myth inherent in the global culture that politics is the world of men. Women politicians do not need to be heavily loaded, because they are considered to enter a world that does not belong to them.

From the above explanation, it can be stated several reasons why women are at the forefront in the arena of our information media world. In other words, the front lines are exploitation and violence. First, the world of television is dominated by men so that women are scattered and only act as complementary sufferers, second, the world of men considers creatures that are female as beautiful and weak creatures. Therefore female creatures are hunted, worshiped and exploited as a medium that smells of sexually by men. Third, the world of television must remain alive in any condition, so only news about sexual activities that mostly involve women are able to support it.

\section{Conclusion}

This study reveals that violence against women in language and the media is an invisible form of violence. Language is a 
person's expression to represent the logic, cultural, social, psychological, philosophical, and political structures of the speakers. It has a goal (teleology) in itself, which is conditioned by the various environmental interests. In patriarchal culture, language is used to build a bad image of women with the aim of strengthening the position of men as the dominant group. The bad image is then used by the media as a general understanding, and implanted into the collective consciousness as the public's subconscious imagination. As a result, whether we realize it or not, women are treated in a subordinate way, but also define themselves in a subordinate way according to men's perspective.

Exploitation of women in language and the media is a form of violence that is often seen as common, even as an order that is no longer possible to change. Harassment of the image and dignity of women through the two entities above is an invisible form of violence. This violence is not only created by a long cultural process but is also created by media and language actors as a form of profit or nonprofit consumption.

To find out the conditions of women's oppression above, feminists and their supporters should be observant and always seek alternative thoughts and movements that can completely break through and resolve the problems of women above, implicitly the problems left by religious interpretation and develop mentalism. In this context, provocations or persuasive writings among Muslim feminists need to be put forward, besides of course more concrete social action. This effort is expected to change and at least give a new color paradigm of thinking about and towards women.
Within certain limits, 'diverting' understanding and interpretation of religion in a direction that is more in line with the vision of the community in order to overhaul patriarchal culture is also absolutely necessary. This is because, religion actually also does not 'subdue' women, but at the same time also has an interest in improving their lot. Because in the essence of each religion itself actually has a mission of liberation and humanity.

In this context, religion can be raised as a strategic force in solving women's problems from the point of women's strategic interests. A number of studies have shown that the problems of Indonesian women have so far been resolved by only considering practical interests, so that the strategic interests of women have been ignored. From this side, religion basically has a big chance for the interests of finding solutions to women's problems. Because religion in itself has the potential as a determinant, inspirator and value standard that cannot be compared with other forces.

\section{References}

\section{Books}

Abduh, Muhammad, (1367), Al-Manar, Kairo: Darul Manar, jilid. I, p. 21.

Abou el Fadl, Khaled M., (2004)., Atas Nama Tuban: dari Fikih Otoriter ke Fikih Otoritatif, transated by R. Cecep Lukman Hakim. Jakarta: Serambi, p. 311.

Abu Zaid, Nasr Hamid, (2011), Women in the Discourse of Crisis, Cairo, Egypt: The Legal Research and Resource center for Human Right pages. (LRRC).

At-Thabari, (2000), Jami' al-Bayan, Kairo: Maktabah al-Syamelah, p. 599. 
Black, James, (1983), The War against Women, London: Penguin, h. 12.

Brownmiller, Susan, (1975), Against Our Will, New York: Oxford University Press, h. 34.

Eagleton, Terry, (2014), Ideology, Routledge, p. 123.

Forum Kajian Kitab Kuning, (2001), Wajah Baru Relasi Suami-Istri, Yogyakarta: LKiS, p. 94.

Foucault, (1972), The Archeology of Knowledge and The Discourse on Language, New York: Pantheon Books, h. 24.

Gadamer, Hans George, (1977), Philosophical Hermeneutics, London: University of Californis press, h. 27.

Hikam, Muhammad AS., (1996), "Bahasa dan Politik; Penghampiran "Discursive Practice" in Yudi Latif and Idi Subandy. Bahasa dan Kekuasaan; Politik Wacana di Panggung Orde Baru. Bandung: Mizan, h. 77.

Ibnu Haldun, (2011), Muqaddimah, Beirut: Darul Fikir, p. 438.

Krippendorff, Klaus, (1981), Content Analysis; Introduction to Its Theory and Methodology, Translated by Farid Wajidi, Jakarta: Rajawali Press, h. 15.

Muhammad bin Iyas, (1982), Bada'i al-Zubur fi Waqai al-Dubur, Beirut: Maktabah Saqafiyyah, p. 52.

Muhammad, Husein, (2001), Fiqh Perempuan; Refleksi Kiai atas Wacana Agama dan Gender, Yogya: LKiS Pelangi Aksara, p. 180-183.

Nursyahbani, (2001), Aspek bukum kekerasan terhadap perempuan, Madura: STAIN Pamekasan Press.

Poerwadarmita, (1980), Kamus Umum Bahasa Indonesia, Bandung: Penerbit Hasta, h. 79.
Rodgerson, Gillian, and Elizabeth Wilson, (1993), Pornography and Feminism; the case against consorship, in Stevi Jackson, New York University Press, p. 288.

Pool, Jonathan, (1990), Language regimes and political regimes In Language policy and political development, Ablex Publishing, h. 241-261.

Sugiyono, (2010), Metode penelitian kuantitatif, kualitatif $\&$ RND. Bandung: Alfabeta.

Suseno, Frans Magnis, (2000), Pengantar melawan kekerasan tanpa kekerasan, Yogyakarta: Pustaka pelajar, p. 56.

Weedon, Chris, (ed.) (1997), Post-War Woman's Writing in German: Feminist Critical Approaches, Berghahn Books, p. 965.

\section{Journals}

Abdillah, Junaidi. Radikalisme Agama: Dekonstruksi Tafsir Ayat-Ayat "Kekerasan" Dalam Al-Qur'an. Kalam: Jurnal Studi Agama dan Pemikiran Islam, Vol. 8, Isuue 2, December 2014, p. 281-300.

Andi, Nofri N, Analisis Terbadap Hadis-Hadis Pemberdayaan Perempuan, Humanisma: Journal of Gender Studies, Vol. 2, issue 2, Juli- Desember 2018, p. 159-166.

Atabik, Ahmad, Wajah Maskulin Tafsir al-Qur'an: studi intertekstualitas ayat-ayat kesetaraan Gender, Palastren: Jurnal Studi Gender, Vol. 6, Issue 2, December 2016, p. 299-322.

Boonzaier, Floretta, The Life and death of Anene Booysen: Colonial discourse, gender-based violence and media representations, South African Journal of Psychology, Vol. 47, Issue 4, 2017, p. 470-481.

Cott, Nancy F., Passionlessness: An interpretation of Victorian sexual ideology, 17901850, Signs: Journal of Women in Culture and Society, Vol. 4, Issue 2, 1978, p. 219-236. 
Damean, Diana, Media and gender: Constructing feminine identities in a postmodern culture, Journal for the Study of Religions and Ideologies, Vol. 5, Issue 14, 2010, p. 89-94.

Davis, Philip M. and William H. Walters, The impact of Free Access to the Scientific Literature: A review of Recent Research, Journal of the Medical Library Association: JMLA, Vol. 99, Issue 3, July 2011, h. 208.

Easteal, Patricia, Kate Holland, and Keziah Judd, Enduring themes and silences in media portrayals of violence against women, Women's Studies International Forum, Vol. 48, Jan-Feb 2014, p. 103113.

Elund, Jude, Masculinity, mass consumerism and subversive sex: $A$ case study of Second Life's 'Zeus' gay club. Sexualities, Vol. 16, Issue 3-4, 2013, p. 423-444.

Eriyanti, Linda Dewi, Pemikiran Johan Galtung tentang Kekerasan dalam Perspektif Feminisme, Jurnal Hubungan Internasional, Vol 6, Issue 1, September 2017, p. 27-37.

Gumiandari, Septi \& Ilman Nafi'a, Women in The Identity Crisis of Feminism; A Critical Analysis on Gender Movement Based on Islamic Psychology Perspective, Humanisma: Journal of Gender Studies, Vol. 3, Issue 1, January-June 2019, p. 1-12

Hald, Gert Martin, Neil M. Malamuth, and Carlin Yuen, Pornography and attitudes supporting violence against women: Revisiting the relationship in nonexperimental studies, Aggressive Behavior: Official Journal of the International Society for Research on Aggression, Vol. 36, Issue 1, 2010, p. 14-20.

Harrigan, Jinni A., and Karen S. Lucic, Attitudes about gender bias in language: $A$ reevaluation, Sex Roles 19. Vol. 3, Issue 4, 1988, p. 129-140.

Johansson, Thomas, and Nils Hammarén, Hegemonic masculinity and pornography: Young people's attitudes toward and relations to pornography, The Journal of Men's Studies, Vol. 15, Issue 1, 2007, p. 57-70.

Johnson, Barbara, The Frame of Reference: Poe, Lacan, Derrida, Yale French Studies, Vol. 55, Issue. 56, July 1977, h. 457-505.

Lisnawati, Lis, Psikolinguistik dalam Pembelajaran Bahasa, Educare, Vol. 6, No. 1, Agustus 2008, h. 31-43.

Mubaligh, Ahmad, Relasi bahasa dan ideology, Lingua: Jurnal Ilmu Bahasa Dan Sastra, Vol. 5, Issue 2, Descmber 2010, h. 112-118.

$\mathrm{Ng}$, S. H., Language-based discrimination: Blatant and subtle forms, Journal of Language and Social Psychology, Vol. 26, 2007, p. 106-122.

Nur Hasnah, Bias Gender Dalam Buku Ajar AlArabiyah Linnaasyiin, Humanisma: Journal of Gender Studies, Vol. 1, Issue 1, January- June 2017, p. 61-74

Rahardjo, Mudjia, Kekerasan Terhadap Perempuan Dalam Bahasa dan Media, El-Harakah; Jurnal Budaya dan Islam, Vo. 3, Issue 1, Jan-March 2018, p. 1-8.

Rodin, Dede, Islam dan Radikalisme: Telaab atas Ayat-ayat Kekerasan dalam al-Qur'an, Addin, Vol 10, Issue 1, February 2016, p. $29-60$.

Santaemilia, José, and Sergio Maruenda, The linguistic representation of gender violence in (written) media discourse: The term 'woman' in Spanish contemporary newspapers, Journal of Language Aggression and Conflict, Vol. 2, Issue 2, January 2014, p. 249273.

Sczesny, S., Formanowicz, M., \& Moser, M., Can gender-fair language reduce gender 
stereotyping \& discrimination?, Frontiers in Psychology, Vol. 7, Issue, 25, 2016, 3-8.

Shodiq, Muhammad Jafar. Bias Gender dalam Buku Bahasa Arab Siswa MA Kelas X dengan Pendekatan Saintifik 2013. Jurnal Pendidikan Islam, Vol. 3, Issue 2, December 2014, p. 307-326.

Sobari, Teri, Kekerasan Simbolik dalam Bahasa Lirik Lagu, Penelitian-Pendikan, Vol. 10, Issue 1, May 2011, p. 144.

Sofiani, Triana, Tafsir Agama Dan Kekerasan Berbasis Gender, Jurnal Penelitian, Vol. 5, Issue 2, November 2013, p. 1-14.

Supadiyanto, Pornography In Print Media: Legal Review Of Pornografic Content On Mantra Tabloid In Indonesia, Journal of Social Studies, Vol. 15, Issue 1, 2019, p. 46-62.

Tranchese, Alessia, and Sole Alba Zollo. The Construction of Gender-based Violence in the British Printed and Broadcast Media, Critical Approaches to Discourse Analysis Across Disciplines, Vol 7, Issue 1, 2013, p.141 - 163.

Watts, Mark D., Elite cues and Media bias in Presidential Campaigns; explaining public perceptions of a liberal press, New York: Communication Research Journal, Sage Publication, Inc, Vol. 26, issue 2, April 1999, p. 144-175.

Wekke, Ismail Suardi, Gender dalam Materi Belajar Bahasa Arab di Pesantren, Turast: Jurnal Penelitian dan Pengabdian, Vol. 1, Issue 1, 2013, p. 55-56.

\section{Report, news and interview}

Jiwani, Yasmin, Symbolic and discursive violence in media representations of Aboriginal missing and murdered women, Understanding violence: Contexts and portrayals (2009): 63-74.

Menegatti, Michela and Monica Rubini, Gender bias and sexism in language, Oxford
Research Encyclopedia of Communication, September 2017, p.124.

Park, Ji Ho, Jamin Shin, and Pascale Fun, Reducing gender bias in abusive language detection, arXiv preprint arXiv:1808.07231 August 2018, p. 1-6.

Putri, Reza Riana, (2012), Kekerasan dalam berpacaran. Dissertation of Universitas Muhammadiyah Surakarta University.

Said, Mas'ud, (2000), Clinton, Wanita dan terpaan Media, Jawa Pos, Kamis, 23 Juli 2000. 